\title{
Targeting Toll-like receptors against cancer
}

\author{
Bing $\mathrm{Du}^{1,2^{*}}$, Qiu-Li Jiang ${ }^{3 *}$, Joseph Cleveland', Bing-Rong Liu², Dekai Zhang ${ }^{1}$ \\ ${ }^{I}$ Center for Infectious and Inflammatory Diseases, Texas A\&M University, Houston, TX 77030, USA. \\ ${ }^{2}$ Department of Gastroenterology and Hepatology, the Second Affiliation Hospital, Harbin Medical University, Harbin 150086, Heilongjiang, China. \\ ${ }^{3}$ Department of Immunology, Harbin Medical University, Harbin 150086, Heilongjiang, China. \\ "The first two authors contributed equally to this paper.
}

Correspondence to: Dr. Dekai Zhang, Center for Infectious and Inflammatory Diseases, Texas A\&M University, 2121 W. Holcombe Blvd., Houston, TX 77030, USA. E-mail: dzhang@ibt.tamhsc.edu; Dr. Bing-Rong Liu, Department of Gastroenterology and Hepatology, the Second Affiliation Hospital, Harbin Medical University, 246 Xuefu Rd., Nangang District, Harbin 150086, China. E-mail: bingrongliu@qq.com

How to cite this article: Du B, Jiang QL, Cleveland J, Liu BR, Zhang D. Targeting Toll-like receptors against cancer. J Cancer Metastasis Treat 2016;2:463-70.

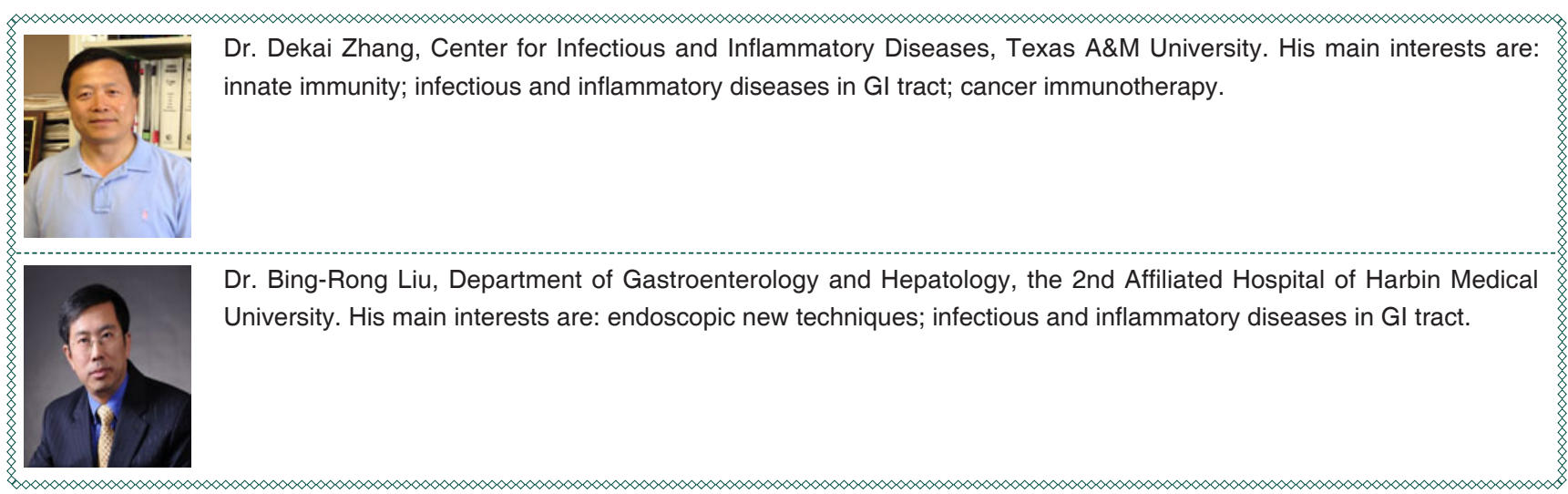

Article history:

Received: 18-10-2016

Accepted: 16-12-2016

Published: 29-12-2016

\section{Key words:}

Toll-like receptor, innate immunity,

cancer,

cancer treatment,

cancer immunotherapy

\section{ABSTRACT}

The discovery of Toll-like receptors (TLRs) about 20 years ago was a remarkable achievement not only in the field of immunology but also in the field of medicine. The TLRs are a family of pattern recognition receptors which play an important role in immune responses by recognizing pathogen-associated molecular patterns. The TLRs also recognize danger-associated molecular patterns, which are associated with some diseases such as cancer. Recent evidence shows that TLRs are expressed not only in immune cells but also in tumor cells. The TLRs appear to play a role in tumor progression and treatment. Most likely, TLR activation has an impact on the initiation, development and treatment of tumors by modulating the inflammatory microenvironment. However, the activation of TLRs contributes to both inhibition and promotion of various tumors, with unclear underlying mechanisms. In this review article, the authors elucidate their current understanding about the role of TLRs in tumor progression, as well as the recent progress in utilizing TLR agonists as potential therapeutic agents in cancer treatment. 


\section{INTRODUCTION}

The discovery of Toll-like receptors (TLRs) approximately twenty years ago is a revolutionary event in life science and medical research, and helps improve our understanding about the role of innate immunity in both the physiology and pathology of human health. The medical community came to realize that innate immunity is essential and critical in immune responses to pathogen infections and in connection with the activation of adaptive immunity. ${ }^{[1-3]}$ Therefore, the 2011 Nobel Prize in Physiology or Medicine was awarded to scientists who made significant contributions to the discoveries concerning TLRs and their role in innate immunity. These discoveries mean that researchers now understand TLR biology much better [Figure 1]. . $^{[4-6]}$ In this article, we summarize the role of TLRs in the immune system and focus on the expression of TLRs in cancer cells and their role in cancer progression. Finally, we discuss the current status of research in utilizing TLR agonists as potential therapeutic agents in cancer treatment.

\section{TLRS: THE KEY SENSORS IN INNATE IMMUNE RESPONSE}

The TLRs are a family of evolutionarily conserved pattern recognition receptors which play a vital role in immune responses against infection. ${ }^{[1-3,7]}$ There are ten TLRs in humans, classified as two subgroups based on their cellular localization:[8] TLR 1, 2, 4, 5, 6 and 10 are located on the cell surface and respond primarily to pathogen-associated molecular patterns (PAMPs) such as lipids and bacterial proteins. In contrast, TLR 3, 7, 8 and 9 are located intracellularly in the endosomes, responding primarily to nucleic acids from both viruses and bacteria. ${ }^{[9]}$ The TLRs are a class of type I transmembrane proteins comprised of an extracellular domain, transmembrane region and intracellular domain. ${ }^{[10]}$ The ectodomain contains leucine-rich repeats and two to four evolutionarily conserved cysteine structures which recognize and bind to evolutionarily conserved molecular motifs in PAMPs. The intracellular domain is highly homologous among the TLRs and contains a toll/interleukin-1 receptor (TIR) domain, which is crucial to the intracellular activation of signaling cascades leading to the induction of pro-inflammatory cytokines and chemokines. ${ }^{[11]}$

The TLRs recognize PAMPs from micro-organisms or danger-associated molecular patterns (DAMPs) from damaged tissues to activate innate and adaptive immune responses. A variety of ligands corresponding to distinct TLRs have been identified so far [Figure 1]..$^{[12-14]}$ For example, TLR2 recognizes peptidoglycan and lipoteichoic acid from bacterial cell wall:;15] TLR3 recognizes double-stranded

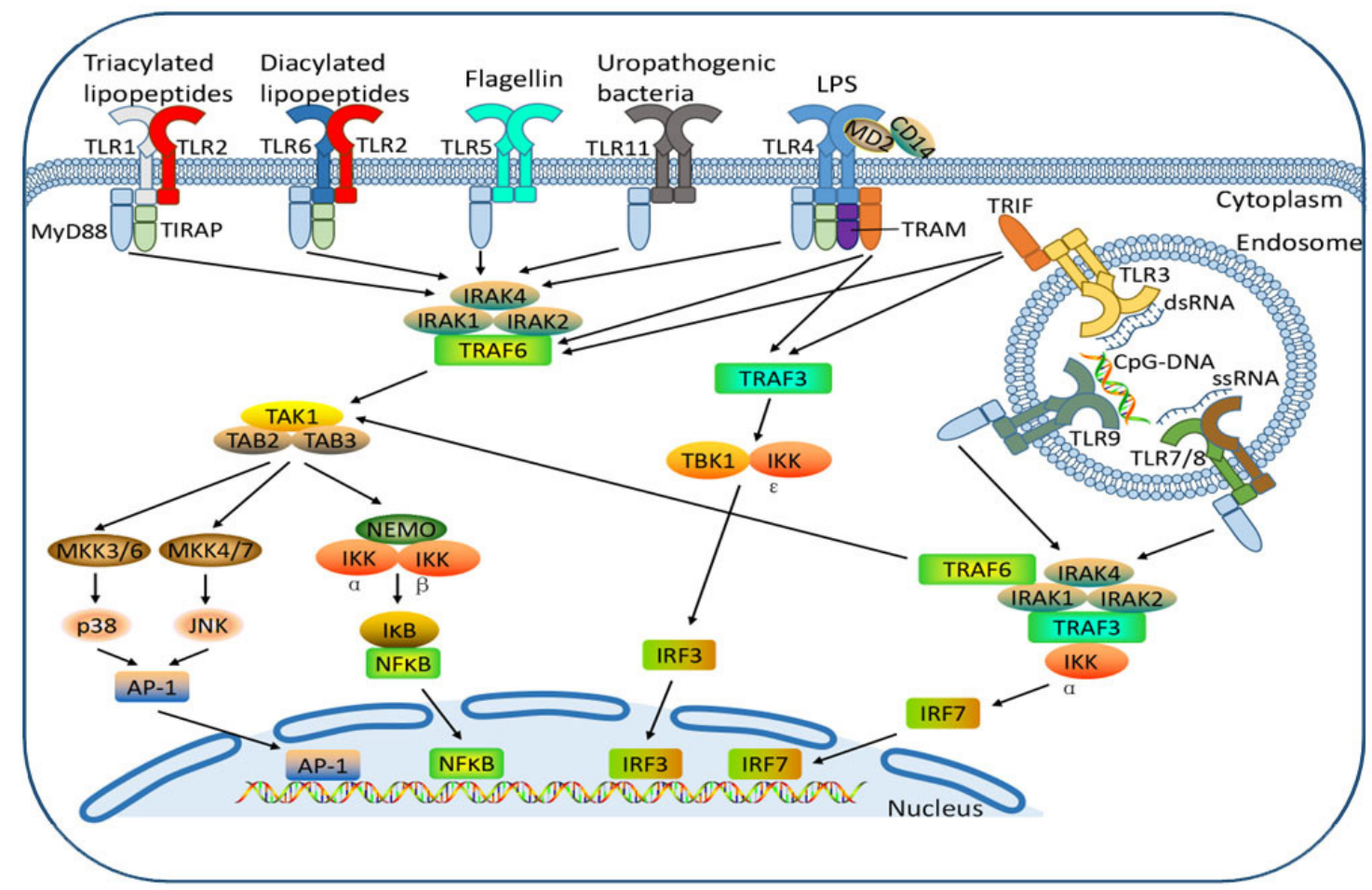

Figure 1: TLR ligands and TLR signaling pathways. Cell surface TLRs, including TLR-1, -2, -4, -5, -6, -10, and -11, and intracellular TLRs, including TLR-3, $-7,-8$, and -9 , recognize their specific PAMPs to activate TLR signaling cascades. ${ }^{[70]}$ TLR: Toll-like receptor; PAMPs: pathogen associated molecular patterns 
RNA (dsRNA) ${ }^{[16]}$ which constitutes the genome of RNA viruses; TLR4 is well known as a sensor of lipopolysaccharide (LPS) from bacteria; ${ }^{[17]}$ TLR5 is responsible for the recognition of flagellin; ${ }^{[18]}$ singlestranded RNA is identified as the ligands of TLR7 and TLR8; ${ }^{[19]}$ and intracellular TLR9 senses unmethylated CpG oligonucleotide (ODN). ${ }^{[2]}$ The specific ligand for TLR10 has not yet been defined. TLR11 in mouse macrophages is known to recognize uropathogenic Escherichia coli, but TLR11 is not expressed in humans. ${ }^{[21]}$

Signaling for TLR is initiated by recognition of PAMPs and the ligand-induced dimerization of TLRs [Figure 1]. Upon activation, TLRs recruit TIR-domaincontaining adaptor proteins for the subsequent activation of downstream signaling. The adaptors include myeloid differentiation factor-88 (MyD88), Toll/ IL-1 receptor domain adaptor protein, TIR-domaincontaining adapter-inducing interferon- $\beta$ (TRIF), TRIF-related adaptor molecule and sterile- $\alpha$ and armadillo motif-containing protein. These adaptors provide receptor sites for relevant proteins and initiate various signaling events, which results in a variety of inflammatory cytokines transcription by mediating the phosphorylation of $I_{\kappa} B \alpha$ to active NF- $\mathrm{NB}$. The multiple signaling pathways contribute to the rapid response of the innate immune system to the pathogens. ${ }^{[22]}$ In addition, the recognition of PAMPs by TLRs gives rise to the activation and maturation of dendritic cells, and pro-inflammatory cytokines and chemokines are produced to induce the proliferation and differentiation of Th1 and Th2, which establishes and regulates adaptive immunity.

\section{TLRS ARE ALSO EXPRESSED IN TUMOR CELLS}

The TLRs, a family of receptors in the innate immune system, are expressed and activated in innate immune cells such as macrophages and dendritic cells. In recent years, however, some studies have shown that TLRs are also highly expressed in various tumor cells. ${ }^{[23-27]}$ For example, over-expression of TLR2, TLR3 and TLR4 has been detected in majority of colonic cancer cells ${ }^{[28,29]}$ and TLR2, TLR3, TLR4 and TLR5 are highly expressed in ovarian cancer cells. ${ }^{[30,31]}$

Therefore, the study of TLR expression and function in cancer has become a focus for researchers. In the colon mucosa of polyposis patients, high mRNA copy numbers of TLR3 have been observed, and strong TLR3 expression has been demonstrated and associated with colorectal cancer stages. ${ }^{[32]}$ Mice deficient in TLR4 and MyD88 have shown significant decreases in the size, incidence and number of chemical-induced liver cancer neoplasms, indicating an important contribution of TLR signaling to hepatocarcinogenesis. ${ }^{[33,34]}$ Two TLRs, TLR5 and TLR9, are considered to be associated with cervical cancer; the expression of these two receptors increases significantly in higher grades of cervical cancer while this expression is rarely detected in normal cervical squamous epithelial cells. ${ }^{[3]}$ The expression of TLR9 promotes angiogenesis and is associated with lower lung cancer survival rates. ${ }^{\left[{ }^{[6]}\right.}$ Moreover, TLR9 promotes the proliferation of prostate cancer cells in time- and dose-dependent manners confirmed by the expression level of NF-kB and downstream c-Myc. ${ }^{[37]}$

Although many TLRs promote the occurrence and development of tumors via a variety of mechanisms, some TLRs might have an antitumor effect. Therefore, the activation of TLRs in cancer cells can play a complex role. The upregulation of TLR1 and TLR2 in bladder cancer promotes the nuclear translocation of NF- $\mathrm{KB}$ and the activation of the c-JNK signaling pathway, which increases the secretion of IL-1, IL-6 and IL-8.

Moreover, TLR3 is considered to promote the death of tumor cells in various cancers. A study by Paone et al. ${ }^{[38]}$ indicated that the TLR3 agonist poly I:C inhibits the proliferation, and promotes the apoptosis, of prostate cancer cells by activating protein kinases. The combination of poly $\mathrm{I}: \mathrm{C}$ and 5 -fluorouracil $(5-\mathrm{FU})$ or IFN- $\alpha$ effectively induced apoptosis in human colon cancer cells. ${ }^{[39]}$ Increased expression of TLR3 in human melanoma can inhibit the proliferation and induce the death of tumor cells with pretreatment of type I IFN. ${ }^{[40]}$ In addition, our study showed that the TLR5- activated signaling pathway in breast cancer inhibits the proliferation of tumor cells by down-regulating cyclin B1, cyclin D1 and cyclin E2. ${ }^{[41]}$ In human head and neck cancers, TLR5 activated by flagellin also reduces tumor cell proliferation and promotes tumor cell apoptosis. When treated with $\mathrm{CpG}$ oligodeoxynucleotides (CpG ODN) 107 and irradiation, the TLR9 signaling pathway in human glioma arrests the cell cycle and reduces the proliferation of tumor cells by activating downstream $\mathrm{NF}-\kappa \mathrm{B}$ and NO pathways. ${ }^{[42]} \mathrm{A}$ TLR9 agonist inhibits proliferation and promotes caspase-dependent apoptosis of neuroblastoma cells. In addition, it has shown antitumor and anti-angiogenesis effects in renal cell carcinoma. ${ }^{[43]}$

The regulation of TLRs and their signal transduction is complicated, and understanding of the mechanism is limited. Recently, the role of autophagy in immune response has drawn special attention because 
TLRs can stimulate autophagy, which conversely regulates TLRs and their signal transduction, with the mechanism unknown. We recently reported that microtubule-associated protein 1S (MAP1S), an intracellular autophagy-related molecule, can regulate TLRs and their signaling. ${ }^{[44]}$ MAP1S plays an important role in cell cycle arrest induced by the flagellin/TLR5 signaling pathway in human breast cancer cell MCF-7, and it is also involved in the inhibition of cell migration of MCF-7 by flagellin. To sum up, given the increasing evidence of mutuality between TLRs and tumors, more attention has been given to innate immunity in tumor cells, especially regarding TLRs expression and signaling pathway, both of which play a significant role in the development of cancer.

\section{TLRs PLAY A CRITICAL ROLE IN TUMOR DEVELOPMENT}

\section{TLR signaling inhibits tumor growth}

The TLRs play an immune surveillance role mainly by inducing the production of multiple cytokines and the activation of immune cells. Cytokines such as type I interferon (IFN-I) and interleukin 12 (IL-12) promote the activation of NK cells and enhance the scavenging capacity of the host with tumor cells. ${ }^{[45]}$ Other cytokines such as IL-2 and IFN- $\gamma$ can enhance the ability of tumor-specific cytotoxic T lymphocyte (CTL) in the host to recognize and scavenge tumor cells. Intriguingly, some TLRs agonists were found capable of inhibiting tumor growth. ${ }^{[46-49]}$ It has been reported that the combination of TLR agonists, chemotherapy drugs and tumor vaccine could improve the efficacy of eliminating tumor cells, an effect mainly based on the activation of antigen-presenting cells and the enhancement of T-cell immune response by TLRs. ${ }^{[50]}$ The increased expression of MHCII, CD88 and CCR7 in the activated antigen presenting cells of the TLRs signaling pathway significantly enhances recognition and presenting to tumor antigen. Also, TLR1/2 acting on $\mathrm{CD}^{+} \mathrm{CTLs}$ increases the secretion of IFN- $\gamma$, TNF- $\alpha$ and IL-2 to promote the secretion of granzyme $\mathrm{B}$ and perforin by $\mathrm{CD}^{+} \mathrm{T}$ cells, which play a key role in elimination of tumor cells. ${ }^{[51]}$

In addition, TLRs also act directly on tumor cells; TLR3 is thought to be effective in promoting tumor cell apoptosis in a variety of tumors. When activated by dsRNA, an agonist of TLR3, breast cancer cells generate autocrine type I IFN, which mediates TLR3 dependent cell apoptosis. ${ }^{[52,53]}$ In type I and II lung cancer cells, the engagement of TLR3 by dsRNA induces an atypical caspase-8-containing complex, which activates apoptotic pathways leading to tumor cell death ${ }^{[53]}$ In the development of tumors, vigorous metabolism leads to metabolic disorders and local hypoxia, through which large amounts of tissue cell debris and proteins are released. The debris and proteins are recognized by TLRs as DAMPs, which are considered signals of danger, and this recognition consequently influences the various biological behaviors of tumor cells. It has been reported that HMGB1, an endogenous ligand of TLR2 which binds to TLR2 and activates TLR2 signaling pathways in glioblastoma, mediates antitumor immune response by inducing the activation of DCs and their migration into the brain tumor. ${ }^{[54]}$

\section{TLR signaling promotes tumor growth}

The activation of TLRs can also promote tumor growth in many situations. Recent studies have found that the combination of highly expressed TLRs and DAMPs in tumors changes the homeostasis of the immune system, which leads to the suppression of immune function. HMGB1 has been identified as a cause of tumors of the skin, liver and pancreas. Furthermore, TLR4 recognizes and combines with HMGB1 released by necrotic cells, and this recognition may eventually cause immune tolerance by activating the downstream pro-inflammatory signaling pathway. At the same time, HMGB1 aggregates in the cell membrane and promotes the invasion and growth of tumor cells. ${ }^{[23]}$

Although the specific mechanisms of TLR-mediated immune escape are still unknown, the high expression of TLRs in tumors often leads to immunosuppression while enhancing the invasiveness of tumors. Studies have found that the activation of the TLRs signaling pathway may lead to increased secretion of IL-10 and TGF- $\beta$, both of which are major immune suppressors in vivo. ${ }^{[55]}$ In addition, the activation of TLRs is also accompanied by the expression of PD-L1, HLA-G and other inhibitory costimulatory molecules. ${ }^{[56]}$ In a mouse model of colon cancer, TLR4 has prolonged the survival time of tumor cells by up-regulating programmed death ligand 1 (PD-L1/B7-H1), inducible costimulator ligand $(\mathrm{B} 7-\mathrm{H} 2)$ and down-regulating the expression level of Fos. ${ }^{[57]}$ Supernatants generated from murine colon cancer cells stimulated with LPS were found to play a significant role in the inhibition of $\mathrm{T}$ cell proliferation and NK cell cytotoxicity. The effect can be reversed after the TLR4 signaling pathway is blocked, which may explain the pathway's immunosuppressive effect. ${ }^{[8]}$ In addition to the inhibiting role, TLRs also promote the proliferation of tumor cells and enhances tumor invasion, promoting immune escape, while TLR2 in human gastric cancer cell lines promotes tumor progression through the induction of COX-2, PGE-2 and IL-8. ${ }^{[57]}$ 
The TLR signaling can lead macrophage polarization change, from M1 (inhibiting tumor) to M2 (promoting tumor), which might explain, at least partially, why TLR signaling promotes tumor growth. The M1/M2 polarization model has been reported in many cancer research studies in recent years. The M1 of tumorassociate macrophages (TAM) express high levels of IL-12 and IL-23, and function as inducers of Th1 responses. During tumor progression, TAM polarizes toward M2 TAM, an alternatively activated macrophage, with a tumor growth-promoting phenotype. However, this $\mathrm{M} 1 / \mathrm{M} 2$ polarization has only been well established in vitro, not in vivo. Therefore, the role of TLR signaling in $\mathrm{M} 1 / \mathrm{Me}$ polarization calls for further investigation.

\section{The role of TLRs in cancer progression: a double-edged sword}

Overall, as discussed above, the activation of TLRs can both promote and inhibit tumor growth and cancer progression, and the underlying mechanism remains elusive. Current knowledge shows that different TLRs share similar signaling pathways, but this cannot explain why the activation of different TLRs in cancers has opposite effects on tumor growth. Also, TLR agonists themselves might have direct pro- or antitumor effects, but current evidence shows that these effects, at least in majority of cases, are very minor. Another potential mechanism is that different TLRs might trigger different signaling pathways in cancer cells. We recently found that activation of TLRs in cancer cells may induce cancer cells to secrete various soluble factors, which might play distinct roles in cancer development. The role of TLRs in cancer progression needs to be further investigated, and understanding the underlying mechanism is essential for the further development of TLR agonists as therapeutic agents.

\section{TLRS IN CANCER TREATMENT}

Since the first TLR was discovered in 1997, ${ }^{[59]}$ studies of the characteristics and prospects of TLRs have become prominent in research. However, the clinical application of TLRs is just beginning ${ }^{[60]}$ To date, only a few TLR agonists have been approved by the Food and Drug Administration for clinical trials involving cancer patients involving Bacillus Calmette-Guérin (BCG), Imiquimod and monophosphoryl lipid A (MPL). Originally used as a vaccine against tuberculosis, BCG is approved for the treatment of bladder cancer; it potently activates TLR2 and TLR4 signaling. ${ }^{[61]}$ Meanwhile, the BCG vaccine is sometimes used to help treat stage III melanoma. ${ }^{[60,62]}$ Imiquimod, a TLR7 agonist which has been in Phase II clinical trials, is efficacious in treatment of various skin tumors and epidermal metastasis, ${ }^{[63]}$ and MPL, a derivative of LPS, is in phase I clinical trials for testing antitumor activity in colorectal cancer patients. At this time MPL has been approved as an adjuvant of Cervarix, a cancer vaccine against HPV-associated cervical cancer. ${ }^{[64]}$

Since the anti-tumor effect of a single TLR agonist remains to be verified and the side effects need to be considered, it may be premature to apply a single TLR agonist to the clinical treatment of tumors. For example, the two-way effects of TLR3 make it a potentially risky therapeutic drug. Although the TLR3 agonist poly A:U is considered to be therapeutically effective in patients with various types of cancers, the risk of metastasis relapse is significantly decreased in TLR3-positive, not in TLR3-negative breast cancers. ${ }^{[65]}$ The function of TLRs in tumors varies with the origin and type of the tumors, which indicates that the therapeutic use of TLR agonists requires much more clinical evidence.

While most of the TLR4 studies reported a tumorpromoting effect, ${ }^{[34,66-69]}$ one study found a protective effect against lung cancer in the lung epithelium. ${ }^{[70]}$ This indicates the need for further study. Nevertheless, the anti-tumor effect of TLRs agonists is still worth exploring. ${ }^{[70-72]}$ The members of the TLR family are different in many aspects such as expression distribution, subcellular localization, adaptive molecules for inducing signal transduction, recognized PAMPs and the types of the induced immune response. Treatment using TLRs ligands has to be based on the identification of the TLRs signals with corresponding diseases, as well as identifying the types of vaccines with significant enhancement that can be used safely and effectively in clinical practice. Future studies should pursue many avenues of research.

\section{CONCLUSION}

The TLRs play a critical role in tumor immunity, and the antitumor effect is also a notable focus for future studies on cancer therapy. The perspective approach for future cancer treatment may be that the combination of some specific TLR agonists or antagonists with traditional cancer treatments might improve treatment efficacy. The role of TLRs in both promoting and inhibiting tumor growth and metastasis has been confirmed in various studies. However, the specific mechanism of action is still unclear; at the same time, cancer is a multifactorial disease, and the research of TLRs on tumor immunity is just beginning. Further studies may help us better understand TLRs and tumor immunity, and the clarification of the roles of TLRs in tumorigenesis and tumor metastasis will provide new strategies and prospects for more effective cancer treatment. 
Financial support and sponsorship

This work was supported in part by NIH Grant CA176698 and the Texas A\&M Health Science Center.

\section{Conflicts of interest}

There are no conflicts of interest.

\section{Patient consent}

There is no patient involved.

\section{Ethics approval}

This article does not contain any studies with human participants or animals.

\section{REFERENCES}

1. Medzhitov R, Janeway CA Jr. Innate immunity: the virtues of a nonclonal system of recognition. Cell 1997;91:295-8.

2. Beutler B. Toll-like receptors: how they work and what they do. Curr Opin Hematol 2002;9:2-10.

3. Akira S, Uematsu S, Takeuchi O. Pathogen recognition and innate immunity. Cell 2006;124:783-801.

4. Pandey S, Kawai T, Akira S. Microbial sensing by Toll-like receptors and intracellular nucleic acid sensors. Cold Spring Harb Perspect Biol 2015;7:a016246.

5. Schenten D, Nish SA, Yu S, Yan X, Lee HK, Brodsky I, Pasman L, Yordy B, Wunderlich FT, Bruning JC, Zhao H, Medzhitov R. Signaling through the adaptor molecule MyD88 in CD4+ T cells is required to overcome suppression by regulatory $\mathrm{T}$ cells. Immunity 2014:40:78-90.

6. Wang Y, Su L, Morin MD, Jones BT, Whitby LR, Surakattula MM, Huang H, Shi H, Choi JH, Wang KW, Moresco EM, Berger M, Zhan $\mathrm{X}$, Zhang H, Boger DL, Beutler B. TLR4/MD-2 activation by a synthetic agonist with no similarity to LPS. Proc Natl Acad Sci U S A 2016;113:E884-93.

7. Kassiotis G, Stoye JP. Immune responses to endogenous retroelements: taking the bad with the good. Nat Rev Immunol 2016;16:207-19.

8. Kawai T, Akira S. Pathogen recognition with Toll-like receptors. Curr Opin Immunol 2005;17:338-44.

9. Maglione PJ, Simchoni N, Cunningham-Rundles C. Toll-like receptor signaling in primary immune deficiencies. Ann N Y Acad Sci 2015;1356:1-21

10. O'Neill LA. Glycolytic reprogramming by TLRs in dendritic cells. Nat Immunol 2014;15:314-5.

11. Santoni M, Andrikou K, Sotte V, Bittoni A, Lanese A, Pellei C, Piva F, Conti A, Nabissi M, Santoni G, Cascinu S. Toll like receptors and pancreatic diseases: from a pathogenetic mechanism to a therapeutic target. Cancer Treat Rev 2015;41:569-76.

12. Kawai T, Akira S. The role of pattern-recognition receptors in innate immunity: update on Toll-like receptors. Nat Immunol 2010;11:373-84.

13. Iwasaki A, Medzhitov R. Control of adaptive immunity by the innate immune system. Nat Immunol 2015;16:343-53.

14. Shah M, Anwar MA, Kim JH, Choi S. Advances in antiviral therapies targeting Toll-like receptors. Expert Opin Investig Drugs 2016;25:437-53

15. Takeuchi O, Hoshino K, Kawai T, Sanjo H, Takada H, Ogawa T, Takeda K, Akira S. Differential roles of TLR2 and TLR4 in recognition of gram-negative and gram-positive bacterial cell wall components. Immunity 1999;11:443-51

16. Alexopoulou L, Holt AC, Medzhitov R, Flavell RA. Recognition of double-stranded RNA and activation of NF-kappaB by Toll-like receptor 3. Nature 2001;413:732-8

17. Poltorak A, He X, Smirnova I, Liu MY, Van Huffel C, Du X, Birdwell D, Alejos E, Silva M, Galanos C, Freudenberg M, RicciardiCastagnoli P, Layton B, Beutler B. Defective LPS signaling in C3H/ $\mathrm{HeJ}$ and $\mathrm{C} 57 \mathrm{BL} / 10 \mathrm{ScCr}$ mice: mutations in Tlr4 gene. Science 1998;282:2085-8

18. Hayashi F, Smith KD, Ozinsky A, Hawn TR, Yi EC, Goodlett DR, Eng JK, Akira S, Underhill DM, Aderem A. The innate immune response to bacterial flagellin is mediated by Toll-like receptor 5 . Nature 2001;410:1099-103.

19. Heil F, Hemmi H, Hochrein H, Ampenberger F, Kirschning C, Akira S Lipford G, Wagner H, Bauer S. Species-specific recognition of singlestranded RNA via toll-like receptor 7 and 8. Science 2004;303:1526-9.

20. Kanzler H, Barrat FJ, Hessel EM, Coffman RL. Therapeutic targeting of innate immunity with Toll-like receptor agonists and antagonists. Nat Med 2007;13:552-9.

21. Zhang D, Zhang G, Hayden MS, Greenblatt MB, Bussey C, Flavell RA, Ghosh S. A toll-like receptor that prevents infection by uropathogenic bacteria. Science 2004;303:1522-6.

22. O'Neill LA, Bowie AG. The family of five: TIR-domain-containing adaptors in Toll-like receptor signalling. Nat Rev Immunol 2007:7:353-64

23. Curtin JF, Liu N, Candolfi M, Xiong W, Assi H, Yagiz K, Edwards MR, Michelsen KS, Kroeger KM, Liu C, Muhammad AK, Clark MC, Arditi M, Comin-Anduix B, Ribas A, Lowenstein PR, Castro MG. HMGB1 mediates endogenous TLR2 activation and brain tumor regression. PLoS Med 2009;6:e10.

24. Ribeiro RA, Wanderley CW, Wong DV, Mota JM, Leite CA, Souza $\mathrm{MH}$, Cunha FQ, Lima-Junior RC. Irinotecan- and 5-fluorouracilinduced intestinal mucositis: insights into pathogenesis and therapeutic perspectives. Cancer Chemother Pharmacol 2016;78:881-93.

25. Kuo WT, Lee TC, Yu LC. Eritoran suppresses colon cancer by altering a functional balance in Toll-like receptors that bind lipopolysaccharide. Cancer Res 2016;76:4684-95.

26. Prakash H, Nadella V, Singh S, Schmitz-Winnenthal H. CD14 TLR4 priming potentially recalibrates and exerts anti-tumor efficacy in tumor associated macrophages in a mouse model of pancreatic carcinoma. Sci Rep 2016;6:31490

27. Llitjos JF, Auffray C, Alby-Laurent F, Rousseau C, Merdji H, Bonilla N, Toubiana J, Belaidouni N, Mira JP, Lucas B, Chiche JD, Pene F. Sepsis-induced expansion of granulocytic myeloid-derived suppressor cells promotes tumour growth through Toll-like receptor 4. J Pathol 2016;239:473-83

28. Fukata M, Chen A, Vamadevan AS, Cohen J, Breglio K, Krishnareddy S, Hsu D, Xu R, Harpaz N, Dannenberg AJ, Subbaramaiah K, Cooper HS, Itzkowitz SH, Abreu MT. Toll-like receptor-4 promotes the development of colitis-associated colorectal tumors. Gastroenterology 2007;133:1869-81.

29. Furrie E, Macfarlane S, Thomson G, Macfarlane GT; Microbiology \& Gut Biology Group; Tayside Tissue \& Tumour Bank. Tolllike receptors-2, -3 and -4 expression patterns on human colon and their regulation by mucosal-associated bacteria. Immunology 2005; $115: 565-74$

30. Zhou M, McFarland-Mancini MM, Funk HM, Husseinzadeh N, Mounajjed T, Drew AF. Toll-like receptor expression in normal ovary and ovarian tumors. Cancer Immunol Immunother 2009;58:1375-85.

31. Kelly MG, Alvero AB, Chen R, Silasi DA, Abrahams VM, Chan S, Visintin I, Rutherford T, Mor G. TLR-4 signaling promotes tumor growth and paclitaxel chemoresistance in ovarian cancer. Cancer Res 2006;66:3859-68

32. Niedzielska I, Niedzielski Z, Tkacz M, Orawczyk T, Ziaja K Starzewski J, Mazurek U, Markowski J. Toll-like receptors and the tendency of normal mucous membrane to transform to polyp or 
colorectal cancer. J Physiol Pharmacol 2009;60 Suppl 1:65-71.

33. Seki E, Brenner DA. Toll-like receptors and adaptor molecules in liver disease: update. Hepatology 2008;48:322-35.

34. Naugler WE, Sakurai T, Kim S, Maeda S, Kim K, Elsharkawy AM, Karin M. Gender disparity in liver cancer due to sex differences in MyD88-dependent IL-6 production. Science 2007;317:121-4.

35. Husseinzadeh N, Davenport SM. Role of toll-like receptors in cervical, endometrial and ovarian cancers: a review. Gynecol Oncol 2014;135:359-63.

36. Belmont L, Rabbe N, Antoine M, Cathelin D, Guignabert C, Kurie J, Cadranel J, Wislez M. Expression of TLR9 in tumor-infiltrating mononuclear cells enhances angiogenesis and is associated with a worse survival in lung cancer. Int J Cancer 2014;134:765-77.

37. Luo Y, Jiang QW, Wu JY, Qiu JG, Zhang WJ, Mei XL, Shi Z, Di JM. Regulation of migration and invasion by Toll-like receptor-9 signaling network in prostate cancer. Oncotarget 2015;6:22564-74.

38. Paone A, Starace D, Galli R, Padula F, De Cesaris P, Filippini A, Ziparo E, Riccioli A. Toll-like receptor 3 triggers apoptosis of human prostate cancer cells through a PKC-alpha-dependent mechanism. Carcinogenesis 2008;29:1334-42.

39. Taura M, Fukuda R, Suico MA, Eguma A, Koga T, Shuto T, Sato T, Morino-Koga S, Kai H. TLR3 induction by anticancer drugs potentiates poly I: C-induced tumor cell apoptosis. Cancer Sci 2010;101:1610-7.

40. Salaun B, Lebecque S, Matikainen S, Rimoldi D, Romero P. Toll-like receptor 3 expressed by melanoma cells as a target for therapy? Clin Cancer Res 2007;13:4565-74.

41. Cai Z, Sanchez A, Shi Z, Zhang T, Liu M, Zhang D. Activation of Toll-like receptor 5 on breast cancer cells by flagellin suppresses cell proliferation and tumor growth. Cancer Res 2011;71:2466-75.

42. Li X, Liu D, Liu X, Jiang W, Zhou W, Yan W, Cen Y, Li B, Cao G, Ding G, Pang X, Sun J, Zheng J, Zhou H. CpG ODN107 potentiates radiosensitivity of human glioma cells via TLR9-mediated NF-kappaB activation and NO production. Tumour Biol 2012;33:1607-18.

43. Damiano V, Rosa R, Formisano L, Nappi L, Gelardi T, Marciano R, Cozzolino I, Troncone G, Agrawal S, Veneziani BM, De Placido S, Bianco R, Tortora G. Toll-like receptor 9 agonist IMO cooperates with everolimus in renal cell carcinoma by interfering with tumour growth and angiogenesis. Br J Cancer 2013;108:1616-23.

44. Shi M, Zhang Y, Liu L, Zhang T, Han F, Cleveland J, Wang F, McKeehan WL, Li Y, Zhang D. MAP1S Protein Regulates the Phagocytosis of Bacteria and Toll-like Receptor (TLR) Signaling. $J$ Biol Chem 2016;291:1243-50.

45. Yuminamochi E, Koike T, Takeda K, Horiuchi I, Okumura K. Interleukin-12- and interferon-gamma-mediated natural killer cell activation by Agaricus blazei Murill. Immunology 2007;121:197-206.

46. Sharma S, Zhu L, Davoodi M, Harris-White M, Lee JM, St John M, Salgia R, Dubinett S. TLR3 agonists and proinflammatory antitumor activities. Expert Opin Ther Targets 2013;17:481-3.

47. Sfondrini L, Rossini A, Besusso D, Merlo A, Tagliabue E, Menard S, Balsari A. Antitumor activity of the TLR-5 ligand flagellin in mouse models of cancer. J Immunol 2006;176:6624-30.

48. Prins RM, Craft N, Bruhn KW, Khan-Farooqi H, Koya RC, Stripecke R, Miller JF, Liau LM. The TLR-7 agonist, imiquimod, enhances dendritic cell survival and promotes tumor antigen-specific $\mathrm{T}$ cell priming: relation to central nervous system antitumor immunity. $J$ Immunol 2006;176:157-64.

49. Kortylewski M, Swiderski P, Herrmann A, Wang L, Kowolik C, Kujawski M, Lee H, Scuto A, Liu Y, Yang C, Deng J, Soifer HS, Raubitschek A, Forman S, Rossi JJ, Pardoll DM, Jove R, Yu H. In vivo delivery of siRNA to immune cells by conjugation to a TLR9 agonist enhances antitumor immune responses. Nat Biotechnol 2009;27:925-32.
50. Davis MB, Vasquez-Dunddel D, Fu J, Albesiano E, Pardoll D, Kim YJ. Intratumoral administration of TLR4 agonist absorbed into a cellular vector improves antitumor responses. Clin Cancer Res 2011;17:3984-92.

51. Geng D, Zheng L, Srivastava R, Asprodites N, Velasco-Gonzalez C, Davila E. When Toll-like receptor and T-cell receptor signals collide: a mechanism for enhanced CD8 T-cell effector function. Blood 2010;116:3494-504

52. Salaun B, Coste I, Rissoan MC, Lebecque SJ, Renno T. TLR3 can directly trigger apoptosis in human cancer cells. J Immunol 2006;176:4894-901.

53. Estornes Y, Toscano F, Virard F, Jacquemin G, Pierrot A, Vanbervliet B, Bonnin M, Lalaoui N, Mercier-Gouy P, Pacheco Y, Salaun B, Renno T, Micheau O, Lebecque S. dsRNA induces apoptosis through an atypical death complex associating TLR3 to caspase-8. Cell Death Differ 2012;19:1482-94.

54. Fucikova J, Moserova I, Urbanova L, Bezu L, Kepp O, Cremer I, Salek C, Strnad P, Kroemer G, Galluzzi L, Spisek R. Prognostic and predictive value of DAMPs and DAMP-associated processes in cancer. Front Immunol 2015;6:402.

55. Jin Y, Wi HJ, Choi MH, Hong ST, Bae YM. Regulation of antiinflammatory cytokines IL-10 and TGF-beta in mouse dendritic cells through treatment with Clonorchis sinensis crude antigen. Exp Mol Med 2014;46:e74.

56. Luddy KA, Robertson-Tessi M, Tafreshi NK, Soliman H, Morse DL. The role of toll-like receptors in colorectal cancer progression: evidence for epithelial to leucocytic transition. Front Immunol 2014;5:429.

57. Kaczanowska S, Joseph AM, Davila E. TLR agonists: our best frenemy in cancer immunotherapy. J Leukoc Biol 2013;93:847-63.

58. Huang B, Zhao J, Li H, He KL, Chen Y, Chen SH, Mayer L, Unkeless JC, Xiong H. Toll-like receptors on tumor cells facilitate evasion of immune surveillance. Cancer Res 2005;65:5009-14.

59. Medzhitov R, Preston-Hurlburt P, Janeway CA Jr. A human homologue of the Drosophila Toll protein signals activation of adaptive immunity. Nature 1997;388:394-7.

60. Vacchelli E, Eggermont A, Sautes-Fridman C, Galon J, Zitvogel L, Kroemer G, Galluzzi L. Trial watch: Toll-like receptor agonists for cancer therapy. Oncoimmunology 2013;2:e25238.

61. Jinesh GG, Kamat AM. Redirecting neutrophils against bladder cancer cells by BCG and Smac mimetic combination. Oncoimmunology 2012;1:1161-2.

62. Bidnur S, Savdie R, Black PC. Inhibiting immune checkpoints for the treatment of bladder cancer. Bladder Cancer 2016;2:15-25.

63. Holcmann M, Drobits B, Sibilia M. How imiquimod licenses plasmacytoid dendritic cells to kill tumors. Oncoimmunology 2012;1:1661-3.

64. Paavonen J, Naud P, Salmeron J, Wheeler CM, Chow SN, Apter D Kitchener H, Castellsague X, Teixeira JC, Skinner SR, Hedrick J, Jaisamrarn U, Limson G, Garland S, Szarewski A, Romanowski B, Aoki FY, Schwarz TF, Poppe WA, Bosch FX, Jenkins D, Hardt K, Zahaf T, Descamps D, StruyfF, Lehtinen M, Dubin G; HPV PATRICIA Study Group. Efficacy of human papillomavirus (HPV)-16/18 AS04adjuvanted vaccine against cervical infection and precancer caused by oncogenic HPV types (PATRICIA): final analysis of a double-blind, randomised study in young women. Lancet 2009;374:301-14.

65. Salaun B, Zitvogel L, Asselin-Paturel C, Morel Y, Chemin K, Dubois C, Massacrier C, Conforti R, Chenard MP, Sabourin JC, Goubar A, Lebecque S, Pierres M, Rimoldi D, Romero P, Andre F. TLR3 as a biomarker for the therapeutic efficacy of double-stranded RNA in breast cancer. Cancer Res 2011;71:1607-14.

66. Chochi K, Ichikura T, Kinoshita M, Majima T, Shinomiya N, Tsujimoto H, Kawabata T, Sugasawa H, Ono S, Seki S, Mochizuki H. Helicobacter 
pylori augments growth of gastric cancers via the lipopolysaccharidetoll-like receptor 4 pathway whereas its lipopolysaccharide attenuates antitumor activities of human mononuclear cells. Clin Cancer Res 2008;14:2909-17.

67. Mittal D, Saccheri F, Venereau E, Pusterla T, Bianchi ME, Rescigno M. TLR4-mediated skin carcinogenesis is dependent on immune and radioresistant cells. EMBO J 2010;29:2242-52.

68. Thuringer D, Hammann A, Benikhlef N, Fourmaux E, Bouchot A, Wettstein G, Solary E, Garrido C. Transactivation of the epidermal growth factor receptor by heat shock protein 90 via Toll-like receptor 4 contributes to the migration of glioblastoma cells. J Biol Chem 2011;286:3418-28.

69. Fukata M, Shang L, Santaolalla R, Sotolongo J, Pastorini C, Espana C, Ungaro R, Harpaz N, Cooper HS, Elson G, Kosco-Vilbois M, Zaias J,
Perez MT, Mayer L, Vamadevan AS, Lira SA, Abreu MT. Constitutive activation of epithelial TLR4 augments inflammatory responses to mucosal injury and drives colitis-associated tumorigenesis. Inflamm Bowel Dis 2011;17:1464-73.

70. Bauer AK, Dixon D, DeGraff LM, Cho HY, Walker CR, Malkinson AM, Kleeberger SR. Toll-like receptor 4 in butylated hydroxytolueneinduced mouse pulmonary inflammation and tumorigenesis. $J$ Natl Cancer Inst 2005;97:1778-81.

71. Zhao S, Zhang Y, Zhang Q, Wang F. Zhang D. Toll-like receptors and prostate cancer. Front Immunol 2014;5:352.

72. Rakoff-Nahoum S, Medzhitov R. Regulation of spontaneous intestinal tumorigenesis through the adaptor protein MyD88. Science 2007;317:124-7. 